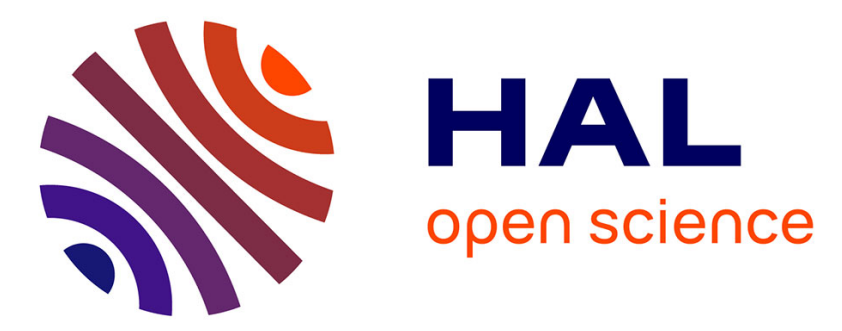

\title{
Some observations about the paper "Earth construction: Lessons from the past for future eco-efficient construction" by F. Pacheco-Torgal and S. Jalali
}

Jean Claude Morel, Jean-Emmanuel Aubert, Younoussa Millogo, Erwan Hamard, Antonin Fabbri

\section{To cite this version:}

Jean Claude Morel, Jean-Emmanuel Aubert, Younoussa Millogo, Erwan Hamard, Antonin Fabbri. Some observations about the paper "Earth construction: Lessons from the past for future eco-efficient construction" by F. Pacheco-Torgal and S. Jalali. Construction and Building Materials, 2013, 44, pp.419-421. 10.1016/j.conbuildmat.2013.02.054 . hal-01744382

\author{
HAL Id: hal-01744382 \\ https://hal.science/hal-01744382
}

Submitted on 27 Mar 2018

HAL is a multi-disciplinary open access archive for the deposit and dissemination of scientific research documents, whether they are published or not. The documents may come from teaching and research institutions in France or abroad, or from public or private research centers.
L'archive ouverte pluridisciplinaire HAL, est destinée au dépôt et à la diffusion de documents scientifiques de niveau recherche, publiés ou non, émanant des établissements d'enseignement et de recherche français ou étrangers, des laboratoires publics ou privés. 
Some observations about the paper "Earth construction: Lessons from the past for future eco-efficient construction" by F. Pacheco-Torgal and S. Jalali

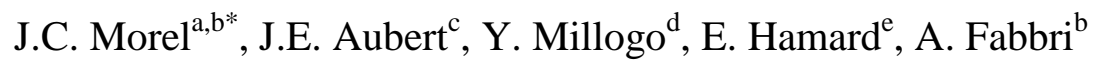 \\ ${ }^{a}$ Laboratoire de Tribologie et Dynamique des Systèmes, UMR 5513CNRS, Ecole Nationale \\ des Travaux Publics de l'Etat, Université de Lyon, Rue Maurice Audin, 69518 Vaulx en Velin \\ cedex, France
}

${ }^{\mathrm{b}}$ Laboratoire de Génie Civil et Bâtiment, Ecole Nationale des Travaux Publics de l'Etat, Université de Lyon, Rue Maurice Audin, 69518 Vaulx en Velin cedex, France

${ }^{\mathrm{c}}$ Université de Toulouse; UPS, INSA; LMDC (Laboratoire Matériaux et Durabilité des Constructions), 135 avenue de Rangueil, F-31 077 Toulouse cedex 4, France

${ }^{\mathrm{d}}$ Unité de Formation et de Recherche en Sciences et Techniques (UFR/ST), Université Polytechnique de Bobo-Dioulasso, 01 BP 1091 Bobo 01, Burkina Faso

${ }^{\mathrm{e}}$ Institut Français des Sciences et Technologies des Transports, de l'Aménagement et des Réseaux; Département Matériaux; GPEM ; route de Bouaye, 44344 Bouguenais, CS4, France

As the starting point of this discussion, we would like to congratulate the authors for this interesting review [1], which defends the use of earth as a building material. Indeed, while this is one of the oldest building materials in the world, it is also one of the less studied by the scientific community, and thus, one of the less understood. However, as stated by the two authors of this review, the number of scientific studies on this subject has increased dramatically in recent years.

There searches on earth as a building material are mainly motivated by the growing demand of masons and construction companies for scientific data and evidence to evaluate and improve the wealth, the hygrothermal comfort and the seismic resistance of earth construction.

First of all, we share the approach proposed by the author that consists of connecting the past and present (and even the future). This point is well illustrated by the first paragraph of the paper and its attractive title. Indeed, we think that the comparisons between the characteristics of modern earthen material sand existing ones, which have proven their effectiveness over the decades, is a major key to improve our understanding of this multi-scale composite material.

The authors wish here to compare their views with those of Pacheco-Torgal and Jalali and highlight the following three main points of disagreement that justify this discussion.

\title{
1. The present and the future of unstabilised earth constructions
}

Throughout the article, the authors seem to postulate that the stabilisation technique (e.g., addition of hydraulic binders) is a compulsory step for earth construction. This leads to quite surprising conclusions about the cost and environmental impacts and their assumed direct link with the nature and amount of the binder used.

These conclusions become even stranger if we consider cement stabilisation, which could be irrelevant from environmental, economic and technical perspectives. Indeed, if this stabilisation is efficient in the case of kaolinic clay materials containing appreciable amount 
of sand [2], the same is not necessarily the case for raw clay materials rich in montmorillonite [3-5].

From this partial point of view on the stabilisation, we can strongly question the consistency displayed by the authors to link traditional earth constructions to the modern use of soil as a building material. Indeed, this former is mostly constituted by structures made of unstabilised earth, even for areas subject to heavy rains (Northern Europe).

As a consequence, while it is true that in some countries, the temptation to accelerate the strengthening of the material by the addition of hydraulic binders can be justified for industrial production rates [6] or for maintenance purposes [2, 7-8], an understanding review should not overshadow the research that is ongoing on un-stabilised earth constructions.

An illustration of the significant importance of taking into consideration both stabilised and unstabilised materials is given in Germany, which is regularly used as a reference by the authors in their review. Indeed, after updating their professional rules, the Dachverband Lehm wrote a draft standard on earth-based bricks considering only un-stabilised bricks (except plant fibres that can be considered as a stabiliser in some cases).

Based on this premise that un-stabilised earth constructions were only useful in the past, the majority of this review loses its relevance and contradicts the title that suggests that we can build the future using knowledge from the past.

This contradiction becomes particularly annoying during the discussions on economic and environmental impacts. The unstabilised earth is solely able to be returned to its initial state (as a soil) without any "waste" of energy, by simply wetting. Moreover, it is possible to reuse the material with the same embodied energy to build again. This is the only material with drystone masonry to be able to do that. Using cement or lime stabilisation increases the embodied energy of the material.

The authors are not at all against the stabilisation, particularly if it is done with the real three dimensions of sustainable building, when for example it enables to use local materials and develop local skills and employment but they are just aware that using earth is not sufficient to be sustainable.

\section{Material properties}

The presentation of the material properties of the soil used for earth construction is interesting but definitely lacks a discussion on the compressive strength. This feature has been extensively studied by various researchers since the 1980s, see for examples [9-29].

Indeed, this characteristic is currently a feature required by all parties involved in construction as a proof of durability. However, there is a paradox between this parameter and the observation of existing earth constructions that have long shown sufficient durability. Thus, despite years of research, there is still no consensus on how to measure this characteristic [27]. As an example, similarly to what it is observed for other building materials, such as concrete, Anglo-Saxon culture advocates the measurement of the "confined" resistance, whereas in French culture, we continue to be attached to the "unconfined" measurements.

Many discussions about the extent and relevance of this feature continue to animate the scientific debate within the community working on this subject.

Moreover, as is rightly stated by the authors, the compressive strength will depend on the sample shape (and this is where the main problem with the compression test lies). However, to echo the previous discussion, it is important to underline here that the stabilisation will also significantly affect the fracture behaviour of the test sample.

Actually, stabilisation created by rigidifying the material will induce a commonly observed behaviour in brittle materials as concrete or stone. In contrast, theun-stabilised material is likely to be closer to conventional behaviour of soils. In this case, the soil behaviour elastoplastic models are a priori better suited to earthen materials [30-31]. 
Thus, any comparison between the compressive strengths of stabilised and unstabilised earth samples should be made with care.

\section{Hygrothermal properties}

Finally, a similar discussion can be undertaken on the hygrothermal properties of earthen materials and their impact on comfort and indoor air quality. One of the main assets that is used to promote earth constructions is their role in controlling moisture and indoor air quality. To our knowledge, there are also few studies that demonstrate what the influence of stabilisation on the hygroscopic behaviour might be. It is well known since [23] that, for materials of the same soils manufactured at the optimum water content, stabilisation increases the volume fraction porosity of the material. The consequence is that the sorptivity of the cement stabilised samples is higher than the unstabilised sample [32]. But recent studies in the moisture buffering in buildings, clearly stated that the vapour transfer were reduced by the stabilisation with lime or cement [33-34]. However, the prediction of this phenomenon through the integration of the measured physical properties of moisture and the heat transfer coupled models is extremely rare [35-37] and should also be completed in further studies.

\section{Conclusions}

We believe that it is necessary to continue discussions among scientists on the use of this material in modern "green buildings". Moreover, it is quite relevant, as suggested by PachecoTorgal and Jalali, to study existing earth constructionsfor, at least, the transmission of cultural know-how. However, the existence of these structures is, by itself, evidence of the durability of these types of constructions, which have remained intact for decades. It will be necessary to increase our knowledge of this material to renovate it properly (including from the energy point of view, for example, in the countries of Northern Europe).

Finally, the question remains open on stabilisation. While it is entirely appropriate for some applications (low-cost buildings in India subjected to the monsoon to avoid having to rebuild every year for example), its routine use in industrialised countries can be questioned. Some local soils are known to exhibit sufficient mechanical characteristics without amendment.

\section{References}

[1] Pacheco-Torgal F, Jalali S. Earth construction: Lessons from the past for future ecoefficient construction. Construc Build Mater 2012;29:512-9.

[2] Millogo Y, Morel JC. Microstructural characterization and mechanical properties of cement stabilised adobes. Mater Struct 2012;45:1311-8.

[3] Molard JP, Camps JP, Laquerbe M. Study of the extrusion and stabilization with cement of monomineralogic clay. Mater Struct 1987;20:44-50.

[4] Ben Amor K, Temimi M, Camps JP, Laquerbe M. Cold stabilization of montmorillonitebased materials using Portland cement. Mater Struct 1997;30:355-61.

[5] Temimi M, Ben Amor K, Camps JP. Making building products by extrusion and cement stabilization: limits of the process with montmorillonite clay. Appl Clay Sci 1998;13:245-53.

[6] Ciancio D, Gibbings J. Experimental investigation on the compressive strength of cored and molded cement-stabilized rammed earth samples. Construc Build Mater 2012;28:294304.

[7] Venkatarama Reddy BV, Prasanna Kumar P. Cement stabilised rammed earth. Part B: Compressive strength and stress-strain characteristics. Mater Struct 2011;44:695-707.

[8] Venkatarama Reddy BV, Prasanna Kumar P. Structural behavior of story-high cementstabilized rammed-earth walls under compression. J Mater Civil Eng 2011;23:240-7.

[9] Walker P. Strength, durability and shrinkage characteristics ofcement stabilised soil blocks. Cem Concr Compos 1995;17(4):301-10. 
[10] Walker P. Characteristics of pressed earth blocks in compression. In:Proceedings of the 11th international brick/block masonry conference,Shanghai, China, 14-16 October; 1997. p. $1-10$.

[11] Venkatarama Reddy BV, Sudhakar MR, Arun Kumar MK. Characteristicsof stabilised mud blocks using ash-modified soils. Indian Concrete J 2003;2(February):903-11.

[12] New Zealand Standard 4298. Materials and workmanship forearth buildings. Standards New Zealand; 1998.

[13] Venkatarama Reddy BV, Jagadish KS. Influence of soil composition onstrength and durability of soil-cement blocks. Indian Concrete J 1995 ;69(9).

[14] Standards Australia Handbook 194. The Australian earth building handbook. Standards Australia, Sydney, Australia; 2002.

[15] Centre for the Development of Enterprise. Compressed earth blockstesting procedures, CDE, Brussels, Belgium; 2000.

[16] Middleton GF. Earth-wall construction, Bulletin 5, CSIRO Division of building, construction and engineering.4th ed. Sydney; 1992[revised by Schneider LM].

[17] Heathcote K, Jankulovski E. Aspect ratio correction factors forsoilcrete blocks. Australian civil engineering transactions, vol. CE34,4. Australia: Institution of Engineers; 1992: 309-12.

[18] Hakimi A, Yamani A, Ouissi H. Rapport: Résultats d'essais derésistance mécaniques sur échantillons de terre comprimée. Mater Struct 1996;29:600-8.

[19] Walker P. Strength and durability testing of earth blocks. In: Proceedings of the 6th international seminar on structural masonryfor developing countries, Bangalore, India; 2000. p. 111-8.

[20] Morel JC, Pkla A, Di benedetto H. Interprétation en compression ou traction de l'essai de flexion en trois points. Rev Fr Génie Civil 2003;7:221-37.

[21] Walker P. Specifications for stabilised pressed earth blocks. Masonry Int 1996;10(1):1-6.

[22] Lunt MG. Stabilised soil blocks for building. Overseas building notes. Garston: Building Research Establishment; 1980.

[23] Olivier M, Mesbah A. Le matériau terre: Essai de compactage statique pour la fabrication de briques de terres compressées. Bull Labo P et Ch 1986;146:37-43.

[24] Heathcote K. Compressive strength of cement stabilised pressed earthblocks. Build Res Inf 1991;19(2):101-5.

[25] Venkatarama Reddy BV, Jagadish KS. Field evaluation of pressedsoil-cement blocks, in In: Proceedings of the 4th international seminaron structural masonry for developing countries, Madras; 1990. p.168-75.

[26] Olivier M, Mesbah A, El Gharbi Z, Morel JC. Mode opératoire pour la réalisation d'essais de résistance sur blocs de terre comprimée. Mater Struct 1997; 30:515-7.

[27] Morel JC, Pkla A, Walker P. Compressive strength testing of compressed earth blocks. Construc Build Mater 2007;21:303-9.

[28] Bui Q B, Morel JC, Hans S, Meunier N. Compression Behavior of nonindustrial materials in civil engineering by three scale experiments : the case of rammed earth. Mater Struct 2009;42:1101-6.

[29] Bui QB, Morel JC. Assessing the anisotropy of rammed earth. Construc Build Mater 2009;23:3005-11.

[30] Nowamooz H, Chazallon C. Finite element modelling of a rammed earth wall. Construc Build Mater 2011; 25: 2112-21.

[31] Jaquin PA, Augarde CE, Gallipoli D, Toll DG. The strength of unstabilised rammed earth materials. Géotechnique 2009;59:487-90.

[32] Hall M, Djerbib Y. Moisture Ingress in Rammed Earth: Part 3 - The Sorptivity and the Surface Inflow Velocity. Construc Build Mater 2006;20(6):384-95. 
[33] McGregor F, Heath A, Ayre G, Fodde E, Walker P. The effect of stabilisation on humidity buffering of earth walls. In: Proceedings of LEHM 2012: 6th International Conference on Building with Earth, oct. 2012, Weimar.

[34] Eckermann W, Ziegert C. Auswirkung von Lehmbaustoffen auf die Raumluftfeuchte, 12p.2006, http://www.boden-

wanddecke.net/lehm/Auswirkung von Lehmbaustoffen auf die Raumluftfeuchte.pdf.

[35] Allinson D, Hall M R. Hygrothermal analysis of a stabilised rammed earth test building in the UK. Energ Build 2010;42:845-52.

[36] Hall MR, Casey SP. Chapter 2: Hygrothermal behaviour and thermal comfort in modern earth buildings. In Hall MR, Lindsay R and Krayenhoff M (Eds.), 2012, Modern earth buildings: materials, engineering, construction and applications, Woodhead Publishing, Cambridge.

[37] Hall M, Allinson D. Analysis of the Hygrothermal Functional Properties of Stabilised Rammed Earth Materials. Build Environ 2009;44(9):1935-42. 